\title{
Life Cycle-Based Sustainability and Circularity Indicators for the Tourism Industry: A Literature Review
}

\author{
Ioannis Arzoumanidis*(D), Anna M. Walker, Luigia Petti $\mathbb{D}$ and Andrea Raggi \\ Department of Economic Studies, University "G. d'Annunzio", 65127 Pescara, Italy; \\ anna.walker@unich.it (A.M.W.); 1.petti@unich.it (L.P.); a.raggi@unich.it (A.R.) \\ * Correspondence: i.arzoumanidis@unich.it
}

check for updates

Citation: Arzoumanidis, I.; Walker

A.M.; Petti, L.; Raggi, A. Life

Cycle-Based Sustainability and Circularity Indicators for the Tourism Industry: A Literature Review. Sustainability 2021, 13, 11853. https:// doi.org/10.3390/su132111853

Academic Editor: Brian Garrod

Received: 17 September 2021

Accepted: 22 October 2021

Published: 27 October 2021

Publisher's Note: MDPI stays neutral with regard to jurisdictional claims in published maps and institutional affiliations.

Copyright: (c) 2021 by the authors. Licensee MDPI, Basel, Switzerland. This article is an open access article distributed under the terms and conditions of the Creative Commons Attribution (CC BY) license (https:// creativecommons.org/licenses/by/ $4.0 /)$.

\begin{abstract}
The tourism industry is one of the fastest growing sectors, even though in the last couple of years there has been a negative effect due to the COVID-19 pandemic. This growth has led to an increase in environmental, economic and social impacts. Furthermore, the transition towards a circular economy has become one of the priorities of the European Union given its orientation towards sustainable development. However, the concept of circular tourism has been poorly analysed until now. This paper aims at identifying a set of life cycle-based sustainability- and circularityrelated indicators for the hospitality sector by means of a literature review and a content analysis. It presents an overview of the most relevant themes and indicators in the tourism sector, showing that carbon footprint and resource-related indicators are especially relevant. Given the complexity of the measurement of circularity and the fact that life cycle-based indicators have started to be considered in this field, the paper also proposes some criteria for indicator selection to make their application more feasible for hospitality actors.
\end{abstract}

Keywords: circular tourism; life cycle assessment; sustainable tourism; accommodation

\section{Introduction}

The tourism industry is one of the fastest growing sectors, with an increase of $5.52 \%$ in arrivals (2017-2019) [1,2], even though the COVID-19 emergency led to a decrease as high as $83 \%$ during the first three months of the year 2021 when compared to 2020 [3]. Despite this, tourism activities cause impacts related to all three conventional sustainability pillars, such as natural ecosystem degradation, seasonal employment, cultural heritage degradation, etc. [4-6]. The United Nations World Tourism Organization (UNWTO) has brought its attention to the promotion of sustainable tourism (ST), which "takes full account of its current and future economic, social and environmental impacts, addressing the needs of visitors, the industry, the environment and host communities" [7].

In order for ST to be successful, the use of appropriate measurement tools for quantification of the level of sustainability as well as the grade of their evolution over time is required [8]. Such tools may also be vital for monitoring sectoral development in order to enable the assessment of tourism policies and practices for measuring sectoral progress and developing suitable strategies for a better future. They can also be used for transferring knowledge through the production of quantitative and objective data that can deliver a richer understanding of tourism-related phenomena [9]. These may include indicators and indices [10] which usually focus more on the main area where the visiting trip takes place (destination level) rather than on a single accommodation (hospitality level) and comprise positive effects (typically economic ones) and negative effects (typically social and environmental ones) [11]. According to Zeppel [12], such indicators/indices are usually simple to measure but tend to consider social aspects less frequently. To this end, several frameworks, systems and mechanisms for sustainability indicators have been developed at an international level—see, for example, the UNWTO indicators for destinations [13], the European Tourism Indicators System [14], the Organisation for Economic Co-operation and 
Development (OECD) indicators for competitiveness [15], the Global Sustainable Tourism Council (GSTC) criteria for hotels and tour operators [16], the European Environment Agency (EEA) indicator-based reporting mechanism [17], etc.

Assessing the multi-dimensional impacts in tourism can be challenging. The concept of life cycle thinking (LCT), with its methodologies-e.g., life cycle assessment (LCA), life cycle costing, social life cycle assessment-covering all three pillars of sustainability, has been increasingly used by the scientific community for products and services, including tourism, given the robustness of such tools $[5,18,19]$.

In line with the UN, the EU has already adopted a sustainable development stance, thus indicating amongst its priorities the transition to a circular economy (CE) [20]. This concept promotes the idea that the value of products as well as that of materials and resources should be maintained for as long as possible within the economy, whilst waste needs to be minimised [21]. When it comes to circular tourism (CT), varying ideas have been proposed regarding a possible definition [4,22]. In theory, the concept of CE (and thus CT) should encompass all three pillars of sustainability [23], even though this is not always true [24]. Indeed, the way a CE can promote sustainable development, and vice versa, remains not comprehensively defined [25]. The $C E$ has been mostly related to environmental benefits [24], whilst the other two pillars appear to have been somehow overlooked [25]. The scientific literature has highlighted the importance of CT when it comes to promoting or achieving sustainable tourism [26-29], whilst others underline the possibility for ST to be a means of reaching $\mathrm{CT}$ and vice versa $[30,31]$.

Within the tourism industry, hospitality is the largest subsector [32], with a great share of impact on an extended version of the three dimensions of sustainability, i.e., economic, governance, social, ethical and environmental [32]. Customers are increasingly aware of such issues and have higher expectations towards accommodation owners and operators [33]. At the same time, customers have been using online booking platforms at an ever increasing rate when booking an accommodation [34,35]. However, to date, there are limited ways for accommodation businesses to report on their sustainability performance to customers when making the booking. To the best of the authors' knowledge, there is no scientific literature on the development and selection of such indicators that are applicable for tourism practitioners.

This article, which builds upon previous research [4,36-38], aims at identifying a set of life cycle-based sustainability- and circularity-related indicators for the hospitality industry by means of a literature review, thus providing some insight towards the relation between the concepts of sustainability and circularity in the sector. This article is structured as follows: first, the procedure of the literature review is provided in Section 2; then, the results are presented and discussed in Section 3; finally, some conclusions are drawn and future developments are illustrated in Section 4.

\section{Materials and Methods}

In order for the research objective to be met, three literature reviews were carried out concurrently using the EBSCO Discovery [39] service (which included both Web of Science and Scopus databases) and subsequent snowballing. The language was not a selection criterion due to the novelty of the topic; therefore, texts in languages other than English were also analysed. The first search concerned literature on sustainable tourism indicator reviews, i.e., a meta-review of studies that assess the impact of tourism on sustainability aspects given the plethora of articles tackling the issue [37]. Secondly, literature on tourismrelated sustainability indicators based on life cycle thinking was analysed because of the robustness of the concept, especially when it comes to individual accommodation assessment and its link to CT [5]. The third search revolved around indicators and assessment approaches specifically for $\mathrm{CT}$, as hospitality companies have started to more systematically apply R-strategies such as reuse, recycling and recovery [4]. The reviews all included the more general term tourism, of which hospitality is a subsector, due to the limited amount of research specifically on hospitality only. All three searches focused on varied 
perspectives from a general point of view (e.g., by using terms, such as tourism) to more accommodation-specific ones (e.g., by using terms such as accommodation, hospitality, hotel, etc.) - please refer to Table 1.

Table 1. Structure of literature reviews.

\begin{tabular}{|c|c|c|c|c|c|c|}
\hline Review Type & (A) & $\begin{array}{l}\text { Meta-review sustainable } \\
\text { tourism assessment }\end{array}$ & (B) & $\begin{array}{l}\text { Sustainable tourism } \\
\text { assessment based on LCT }\end{array}$ & (C) & $\begin{array}{l}\text { Circular tourism } \\
\text { assessment }\end{array}$ \\
\hline Search Terms & \multicolumn{2}{|c|}{$\begin{array}{l}\text { (sustainab* OR environ* OR social } \\
\text { OR economic) AND (touris* OR } \\
\text { hospitality OR accommodation* } \\
\text { OR hotel* OR hostel* OR } \\
\text { "bed-and-breakfast") AND } \\
\text { (assess* OR measure* OR metric* } \\
\text { OR indicator*) AND (review) }\end{array}$} & \multicolumn{2}{|c|}{$\begin{array}{l}\text { (sustainab* OR environ* OR social } \\
\text { OR economic) AND (touris* OR } \\
\text { hospitality OR accommodation* } \\
\text { OR hotel* OR hostel* OR } \\
\text { "bed-and-breakfast") AND } \\
\text { (assess* OR measure* OR metric* } \\
\text { OR indicator*) AND (life) AND } \\
\text { (cycle) }\end{array}$} & \multicolumn{2}{|c|}{$\begin{array}{l}\left(\text { circular }^{*}\right) \text { AND (touris* OR } \\
\text { hospitality OR } \\
\text { accommodation* OR hotel* } \\
\text { OR hostel* OR } \\
\text { "bed-and-breakfast") AND } \\
\text { (assess* OR measure* OR } \\
\text { metric* OR indicator })\end{array}$} \\
\hline Inclusion Criteria & - & $\begin{array}{l}\text { Specifically on } \\
\text { assessment/indicators }\end{array}$ & - & $\begin{array}{l}\text { Specifically on } \\
\text { assessment/indicators }\end{array}$ & - & $\begin{array}{l}\text { Specifically on } \\
\text { assessment/indicators }\end{array}$ \\
\hline Exclusion Criteria & & $\begin{array}{l}\text { Not relevant } \\
\text { Not available }\end{array}$ & & $\begin{array}{l}\text { Not relevant } \\
\text { Not available }\end{array}$ & $\begin{array}{l}- \\
-\end{array}$ & $\begin{array}{l}\text { Review, editorial } \\
\text { Not available }\end{array}$ \\
\hline
\end{tabular}

For literature review " $\mathrm{A}$ ", 21 results were found. After the inclusion/exclusion criteria were taken into account, 8 articles [8-10,40-44] were selected. All of them are quite recent: one is from 2007 whilst the rest are from 2014 onwards, and half of them are from 2020. With regard to literature review " $\mathrm{B}$ ", 648 results were found. The implementation of the inclusion/exclusion criteria resulted in 14 works [45-58] (11 articles, 2 book chapters and 1 thesis), out of which 10 are in English, 1 is in Spanish and 1 is in Portuguese. The findings are recent (from 2011 onwards; two of them are from 2021). For literature review " $C$ ", after the title search, 71 publications remained from 694 (of which many were duplicates). After the abstract search, 30 papers were selected for full-text search, of which 9 were considered [59-67] for the final analysis. All of them are recent (from 2011 onwards).

Through a content analysis [68], the authors extracted the indicators proposed in the literature and grouped them into themes in an iterative process. This was conducted separately by the authors in a first step, whereafter they compared their themes and corresponding categorisation of indicators and streamlined their results. Simultaneously, the indicators were consolidated to make them more generic in nature so as to allow for wider applicability.

\section{Results and Discussion}

The following subsections first present the findings of each of the three reviews (summarised in Table S1-Supplementary Materials) and then provide options for further analysis. It is to be highlighted that the results summarised in Table S1 refer to indicators/indices as they were retrieved from the various articles, thus not necessarily representing the opinions of the authors of this article. Indeed, according to the authors, in some cases, indicators/indices have been misplaced under the pillars-e.g., litter/pollution was placed under the social pillar [10]. Finally, an overview of the most frequently mentioned themes and indicators throughout all reviews is presented in Table 2. The indicators are divided into energy-related, resource- and waste-related, impact-related, land-related, socio-economic and socio-cultural themes. Within each theme, the indicators are ranked according to their occurrence. 
Table 2. Themes with most frequently mentioned indicators.

\begin{tabular}{|c|c|}
\hline & Energy-Related \\
\hline 1 & Energy use \\
\hline \multirow[t]{2}{*}{2} & Renewable energy use \\
\hline & Resources/Waste-Related \\
\hline 1 & Water supply/use \\
\hline 2 & Recycling rate \\
\hline 3 & Waste generation rate \\
\hline 4 & Water treatment \\
\hline \multirow[t]{2}{*}{5} & Water quality \\
\hline & Impact-Related \\
\hline 1 & Climate change \\
\hline 2 & Biodiversity \\
\hline 3 & Acidification \\
\hline 4 & Nutrient enrichment \\
\hline \multirow[t]{2}{*}{5} & Photochemical oxidants \\
\hline & Socio-Economic \\
\hline 1 & Employment \\
\hline 2 & Health and safety \\
\hline 3 & Number of tourists \\
\hline 4 & Local community benefits/damages \\
\hline \multirow[t]{2}{*}{5} & Infrastructure investments \\
\hline & Socio-Cultural \\
\hline 1 & Cultural heritage \\
\hline 2 & Local identity \\
\hline 3 & Gender equality \\
\hline 4 & Cultural richness and exchange/environmental education \\
\hline 5 & Satisfaction of tourists \\
\hline 6 & Local people's perception of tourists \\
\hline \multirow[t]{2}{*}{7} & Security \\
\hline & Land-Related \\
\hline 1 & Land management/use \\
\hline 2 & Landscape/visual pollution \\
\hline 3 & Coastal zone erosion \\
\hline 4 & Urbanisation \\
\hline 5 & Land conservation \\
\hline
\end{tabular}

\subsection{Sustainability Indicators}

The identified publications (please refer to Table S1) were then analysed in terms of the proposed sets of indicators. As a general finding, it seems that the issue of identifying life cycle-based sustainability indicators for the tourism industry, and more specifically for the hospitality subsector, has been poorly addressed so far, thus confirming previous studies [36,37].

In contrast, when it comes to sustainability indicators in general, the meta-review showed a plethora of publications that have tackled this issue hitherto as well as several international frameworks, systems and mechanisms [13-17]. In terms of specific foci within the tourism industry, the analysed reviews [8-10,40-44] focused in general on tourism; three 
of them explicitly focused on the destination level $[9,40,43]$, whilst none of them specifically tackled the hospitality subsector. Another significant finding for the main objective of this article was that none of these reviews mentioned whether the identified or proposed sets of indicators could be considered as life cycle-related. In fact, some of the reviews did not provide indicators at all but rather a thorough discussion on them $[41,42,44]$; for this reason, they were considered in the analysis as a contribution to the discussion. On the other hand, three of them explicitly considered the three pillars of sustainability separately, therefore providing environmental, economic and social indicators [8-10], whilst Marković Vukadin et al. [9] provided social along with cultural ones. Finally, two reviews $[40,43]$ provided sustainability indicators, without clearly citing any of the pillars.

In general, the proposed indicators appeared to range from measuring specific aspects to more generic ones. Indicators such as "production of energy from renewable sources" [10], "waste generated" [40] and "expenditure per tourist night" [43] are examples of more specific indicators, whilst "reducing impact", "visitor fulfilment" [8] and "clean food and tourism" [43] can be seen as more generic, qualitative in some cases, indicators to assess sustainability. In most cases, sustainability indicators refer to energy/resource efficiency [8-10,40], waste generation $[9,10,40]$ and water consumption and/or quality $[9,10,40]$ for the environmental pillar. Regarding the economic one, indicators related to expenditures per tourist $[10,43]$ and occupancy rate of accommodations/net tourism receipts $[10,43]$ were mentioned more frequently. Finally, for the social pillar, local community [8-10,40], visitor satisfaction $[8,10]$ and cultural heritage $[8,9]$ were amongst the most cited. It must be mentioned that in some cases, the sustainability indicators considered by some authors under one pillar could actually also be associated under another one-e.g., "health and safety" and "local community" were sometimes considered to be "economic", but they could also be considered as "social" [69].

In one review [40], international framework/scheme indicators were provided that follow different perspectives: pressure/stress (caused by human activities that affect environment, culture and economy), state (current state of the industry), response (of society and management efforts to solve problems identified by other indicators), impact (on the social and economic roles of the tourism destination), performance (distance to target of the industry), efficiency (of human activities to resolve identified problems; comparison of gain and expenditure) and early warning (apparent changes that could influence the sustainability of the industry). Torres-Delgado and Saarinen [10] identified several sustainability indicators based on different scientific articles whilst explicitly citing the three pillars of sustainability in three cases [70-72].

\subsection{Life Cycle-Based Sustainability Indicators}

When it comes to life cycle-based sustainability indicators, literature review " $\mathrm{B}$ " revealed two different thinking concepts for defining the life cycle: one follows the LCT $[5,18,36,37]$ (focusing on the physical life cycle of a product or a service from raw materials extraction to production, distribution, use and end-of-life treatment), whilst the second one follows the tourist area life cycle (TALC) evolution [73] (focusing on the market life cycle of a tourist area, from exploration to involvement of local residents and to development, consolidation, stagnation and finally decline or rejuvenation of the area). As mentioned in Section 1, the objective of this ongoing project concerns the LCT concept given the consolidated robustness of its methodologies that embrace the three pillars of sustainability. However, the results related to the TALC concept were not excluded from this analysis as (i) they were technically life cycle-related; (ii) in many cases, they provided similar results to the LCT-based ones; and (iii) the tourist areas/destinations had been considered in literature review " $\mathrm{A}$ ", as well.

The analysis of the results showed three publications that actually propose a "one-fitsall solution" of a single indicator that could sufficiently cover both carbon footprint/climate change [53,54] and energy use [45]. Carbon footprint was also present in other sets of proposed indicators along with other environment-related ones [49-52]. Other frequently men- 
tioned environmental indicators included energy efficiency/consumption [50-52,58] and acidification $[49,52]$. When it comes to the economic pillar, only a limited number of cases tackled it in an explicit way, mainly via the contribution of tourism to income $[46,47,50]$ or job creation $[46,47]$, even though their connection to the LCT concept is not clear. Finally, regarding the social pillar, indicators related to the impact category of health (and safety) appeared to be most mentioned $[46,48,50]$, followed by indicators concerning the stakeholder local community $[46,48,50]$ and employment issues $[47,48,50]$.

Steinmann et al. [52] attempted to identify a set of environmental life cycle-based indicators from the Ecoinvent database that would be optimal and representative of all of them by using a combination of the principal component analysis (PCA) with an optimisation algorithm for almost 1000 products (even though tourism as a service was not explicitly mentioned). The results interestingly reported at a high variance of products that such a set of indicators would include global warming, land use, ozone depletion, (the combined effect of) acidification and eutrophication and terrestrial and marine ecotoxicity [52]. Lowering such variance from 92 to $84 \%$, the set can be further reduced in terms of the number of indicators, thus including energy, water, land and materials [52].

Another set of environmental life cycle-based indicators with a specific application on a defined area of concentrated tourism (DACT) was formulated as a composite indicator (Tourism Environmental Composite Indicator-TECI), which included energy, water, waste and carbon footprint (for hotels and for transport) [51]. Being somewhat connected to the tourism industry, inclusion of indicators such as accommodation, thermal energy, electricity, road transport, air travel and food was also proposed-or, alternatively, as previously mentioned, the use of a single indicator, i.e., carbon footprint for the residences [53]. Furthermore, Filimonau [49] mentioned a set of the most frequently influenced impact categories specifically for the tourism sector, comprising acidification, nutrient enrichment and photochemical oxidants as well as climate change. Finally, a set including loss of biodiversity, land management, energy use and climate change was also proposed [50].

\subsection{Circularity Indicators}

With regard to circularity indicators resulting from review " $\mathrm{C}$ ", interestingly, most of the papers were written in the past five years, while in China, the term "circular tourism" had existed for longer [74], explaining the earlier publication of Zhao and Tao [59]. In contrast, the concept has appeared more recently in English literature, and as can be seen from the limited number of results, the development of indicators to assess circularity is still in its infancy. Instead, several publications [75-77] on CT focus on the circular practices of tourism services, mainly including the R-hierarchy, without assessing the impact of these practices.

The papers explicitly mentioning the $\mathrm{CE}$ in connection with assessment often do so without explaining why the assessment approaches they chose were suitable to establish the circularity of the tourism service. For instance, Maugeri et al. [61] conducted an LCA of a one-night stay at a hotel in the context of $C E$ but failed to mention how their case differs from a sustainable tourism case. In a similar manner, Pan et al. [63] and Randazzo et al. [64] presented indicators which could also be ascribed to green or sustainable tourism, related to renewable energy, lowering carbon emissions, circular resource use (most closely related to $C E$ ) and education for the local population. Nocca [62] identified indicators from case studies on cultural heritage and found that the managers of the sights involved in the study were indifferent to whether the tourism should develop in a linear or circular way. However, there were several indicators related to building restoration and refunctionalisation that could, in theory, be ascribed to circularity, as visible in Table S1 [62]. Another group of papers was mainly concerned with waste-related indicators. Voukkali et al. [67] created several indices related to waste for coastal municipalities, whereas Son et al. [65] developed indicators to document the recycling behaviour of hotels in Vietnam, though without explicitly mentioning the circular economy. On a broader scale, Hartley-Ballestero and Suárez-Espinoza [66] analysed regional circularity indicators of tourism areas in Costa 
Rica, which are mainly related to the management of community and biodiversity, spatial planning and the water cycle. The papers of Scheepens et al. [60] and Zhao and Tao [59] are directly related to the assessment of the CE in tourism. Scheepens et al. [60] were the first to apply two LCA-based methodologies to the water tourism sector, namely the eco-costs/value ratio model to analyse the potential environmental impacts of business initiatives, and the circular transition framework. The latter covers the whole product life cycle to help understand what forms the design of circular business models could take and how these business models could be introduced. In contrast, Zhao and Tao [59] conducted a Delphi study with an analytic hierarchy process to identify eight indicators to assess $\mathrm{CT}$ spots which revolve around resource efficiency and recycling as well as economic, social and environmental impacts. These are similar in scope to the ones proposed by Hartley-Ballestero and Suárez-Espinoza [66], though the latter are more extensive and more focused on water management.

\subsection{Further Analysis}

The selection of appropriate indicators can be quite complex and may depend on the issue to be handled and on the form of measurement that is expected to be accomplished [42], whilst stakeholder consultation and planning may be fundamental steps [56,71]. In general, in order for an inclusive set of indicators to be selected, a series of criteria would need to be met. These may be numerous, comprising criteria such as relevance, scientific precision, measurability, transparency, adaptability, comparability, updating, cost efficiency, territorial representation, temporal representation, sensitivity, communication and participation [10], or sometimes they can be summarised in a less extensive set, comprising criteria such as relevant, accepted, credible, easy and robust [50]. In the case of implementation of such indicators in the hospitality industry, one would have to consider criteria such as being scientifically robust, simple to calculate and usable for both accommodations and clients [38].

Most of the proposed sets are related to international frameworks and/or schemes [13-17]. However, the relevance of the identified indicators to the tourism industry, and more precisely to the hospitality subsector, has not always been clear. In many cases, the indicators were proposed in general or for a great number of products/sectors (including tourism) or tourism destinations; however, only in a limited number of publications was a clear connection made to accommodations. It is to be highlighted that such a connection was clearly made only for recycling rate [64] and carbon footprint or climate change [51,53,78], although the use of it as a proxy for all indicators was criticised for systems where the impacts are not only connected to a few activities, such as consumption of energy and/or a small number of resources [53]. In the case of hospitality, such a limit could depend on the type of accommodation-e.g., the number of activities and/or material/energy flows cannot be the same for a small B\&B and for a five-star hotel.

Keeping the criteria for indicator selection in mind, this paper provides a first overview of indicators or indicator sets (Table 2) that could be important to assess for actors in the hospitality sector that are moving towards sustainable CT. The themes cover ST-, LCT- and CT-based indicators, which each cover similar but slightly different topics. While in ST and LCT there is a stronger focus on sociocultural indicators, CT is more concerned with resource- and waste-related indicators. As could be expected, it was also found that the review on LCT-based indicators proposed more indicators related to LCA impact categories.

Regarding the conceptualisation of indicators, the specific position of tourism, and particularly the hospitality services, should also be taken into account. Accommodation can essentially be seen as a service of durable goods (for instance, a hotel room with its furniture and equipment) which are rented to customers over and over, thus showing characteristics of a product service system [38]. After conducting an initial life cycle-based assessment, in line with the underlying rationale of $\mathrm{CT}$, the best solution to provide the function of "staying one night" can be identified. It will determine whether the accommodation owners should opt for reusable or single-use options, especially concerning amenities. For 
continuous monitoring of the impact, a simpler assessment could then be designed against the background of maximising the durability of the rented products through maintenance, while minimising the throughput of related single-use products (for example, the amenities in hotel rooms) and managing their disposal. After a more comprehensive assessment (for example, an LCA), accommodations could, hence, map the products needed per guest and separate them into durable and single-use products then to be matched with the respective assessment approach.

\section{Conclusions}

The tourism industry is one of the fastest growing sectors, even though in the last couple of years there has been a negative effect due to the COVID-19 pandemic. This growth has led to an increase in sustainability-related impacts. Furthermore, the transition towards a CE has become one of the priorities of the European Union given its stance towards sustainability. However, the concept of circular tourism has been poorly analysed until now. This paper aimed at identifying a set of life cycle-based sustainability and circularity-related indicators for the hospitality sector drawing from the literature on sustainable tourism and indicators related to LCT and CT.

In general, the sustainability indicators appeared to differentiate from the life cyclebased and the circularity indicators as the former also included socio-economic and sociocultural aspects. Sustainability indicators have been proposed by international organisations and frameworks and have been studied in depth by the scientific community for the tourism industry. However, specific sustainability indicators have rarely been addressed or specified for the hospitality subsector. The same also goes for life cycle-based sustainability indicators for the tourism industry in general, let alone for the hospitality subsector. It seemed that carbon footprint/climate change has been mentioned most often (though also criticised in other cases) to be used as a life cycle-based sustainability indicator for tourism and for hospitality, either alone (as a proxy) or amongst other indicators. Other commonly used LCA indicators included acidification and nutrient enrichment/eutrophication. With regard to circularity indicators, it appeared that recycling rate and waste-related indicators were most commonly mentioned, even though it was found that the CT literature is still preoccupied with practices rather than their assessment. Furthermore, it was proposed that an impact assessment of hotel services could be carried out according to circularity strategy (durable vs. single-use).

Besides a description of the literature on sustainable, LCT-based and circular tourism indicators, this paper also contributes with a first analysis and selection of relevant indicator themes and subcategories that can be used by practitioners wanting to assess a hospitality business' contribution towards more sustainable development through CT.

Future developments within the framework of an ongoing EU-funded project ("AIMAttraction and International Mobility") will include the identification of life cycle-based, scientifically sound and easy-to-use sustainability indicators and circularity indicators to be used in online booking platforms. This will be performed also via the implementation of life cycle sustainability assessment (LCSA) case studies, which will result in the identification of the most frequently mentioned indicators. Finally, the indicators that have been identified through this literature review along with the ones identified via the LCSA case studies will be used in decision-making tools (e.g., analytic hierarchy process, Delphi) by involving relevant stakeholders (e.g., tourism experts, tour operators, accommodation owners, online booking platform operators, etc.) in order for the most suitable to be selected. 
Supplementary Materials: The following are available online at https:/ / www.mdpi.com/article/10 .3390 /su132111853/s1, Table S1: Sustainability and circularity indicators for tourism-findings of the three literature reviews [8-10,13,40-67,70-72,79-81].

Funding: This research is part of the "AIM-Attraction and International Mobility" project of the Italian National Operational Programme (PON), funded by the European Social Fund and the Italian Revolving Fund (AIM1894803-1).

Conflicts of Interest: The authors declare no conflict of interest.

\section{References}

1. UNWTO. World Tourism Organization (UNWTO) World Tourism Barometer and Statistical Annex; UNWTO: Madrid, Spain, $2020 ; 18$.

2. Polyzos, S.; Samitas, A.; Spiridoy, A.E. Tourism demand and the COVID-19 pandemic: An LSTM approach. Tour. Recreat. Res. 2021, 46, 175-187.

3. UNWTO. World Tourism Organization (UNWTO) World Tourism Barometer and Statistical Annex; UNWTO: Madrid, Spain, $2021 ; 19$.

4. Arzoumanidis, I.; Mancini, E.; Walker, A.M.; Petti, L.; Raggi, A. Towards a definition of Circular Tourism: A literature review. In Le scienze merceologiche nell'era 4.0-XXIX Congresso Nazionale di Scienze Merceologiche 2020—Atti del Convegno, Proceedings of the 29th Italian Congress on Commodity Science, Salerno, Italy, 13-14 February 2020; Esposito, B., Malandrino, O., Sessa, M.R., Sica, D., Eds.; FrancoAngeli: Milan, Italy, 2020; pp. 44-52.

5. Filimonau, V. Life cycle assessment. In The Routledge Handbook of Tourism and Sustainability, 1st ed.; Hall, C.M., Gossling, S., Scott, D., Eds.; Routledge: Oxon, UK, 2015; pp. 209-220.

6. Tasci, A.D.A. Consumer demand for sustainability benchmarks in tourism and hospitality. Tour. Rev. 2017, 72, 375-391. [CrossRef]

7. UNWTO. Sustainable Development. Available online: https://www.unwto.org/sustainable-development (accessed on 21 August 2021).

8. Purwaningsih, R.; Agusti, F.; Nugroho, W.P.S.; Susanty, A.; Purwanggono, B. Assessment sustainable tourism: A literature review composite indicator. E3S Web Conf. 2020, 202, 03001. [CrossRef]

9. Marković Vukadin, I.; Zovko, M.; Krešić, D. Review and evaluation of existing international systems of tourism sustainability indicators. Croat. Geogr. Bull. 2020, 82, 85-110. [CrossRef]

10. Torres-Delgado, A.; Saarinen, J. Using indicators to assess sustainable tourism development: A review. Tour. Geogr. 2014, 16, 31-47. [CrossRef]

11. Volo, S. Indicatori Nel Turismo: Fondamenti Teorici, Evidenze Empiriche e Implicazioni Manageriali, 1st ed.; Aracne Editrice: Canterano, Italy, 2017. (In Italian)

12. Zeppel, H. Environmental indicators and benchmarking for sustainable tourism development. In The Routledge Handbook of Tourism and Sustainability, 1st ed.; Hall, C.M., Gossling, S., Scott, D., Eds.; Routledge: Oxon, UK, 2015; pp. 187-199.

13. UNWTO. Indicators of Sustainable Development for Tourism Destinations a Guidebook; UNWTO: Madrid, Spain, 2004.

14. European Commission. The European Tourism Indicator System ETIS Toolkit for Sustainable Destination Management; European Union: Luxembourg, 2016.

15. Dupeyras, A.; MacCallum, N. Indicators for Measuring Competitiveness in Tourism: A Guidance Document; OECD Publishing: Paris, France, 2013; 2013/02.

16. Global Sustainable Tourism Council (GSTC). Global Sustainable Tourism Council Criteria with Suggested Performance Indicators for Hotels and Tour Operators, Version 3; GSTC: Salt Lake City, UT, USA, 2016.

17. Giulietti, S.; Romagosa, F.; Fons, J.; Schröder, C. Developing a “Tourism and Environment Reporting Mechanism” (TOUERM): Environmental impacts and sustainability trends of tourism in Europe. In Proceedings of the 14th Global Forum on Tourism Statistics, Venice, Italy, 23-25 November 2016.

18. Jęczmyk, A.; Kasprzak, K. Zastosowanie środowiskowej oceny cyklu życia (LCA) w turystyce-Application of Environmental Life Cycle Assessment (LCA) in tourism. Pol. J. Sustain. Dev. 2018, 22, 2. (In Polish)

19. De Camillis, C.; Raggi, A.; Petti, L. Tourism LCA: State-of-the-art and perspectives. Int. J. Life Cycle Assess. 2010, 15, 148-155. [CrossRef]

20. European Commission. Communication from the Commission to the European Parliament, the Council, the European Economic and Social Committee and the Committee of the Regions: Closing the Loop-An EU Action Plan for the Circular Economy. COM (2015) 614. Available online: https:/ / ec.europa.eu/transparency/regdoc/rep/1/2015/EN/1-2015-614-EN-F1-1.PDF (accessed on 25 July 2021).

21. Pamfilie, R.; Firoiu, D.; Croitoru, A.-D.; Ioan Ionescu, G.H. Circular economy-A new direction for the sustainability of the hotel industry in Romania? Amfiteatru Econ. 2018, 20, 388-404.

22. Rodríguez, C.; Florido, C.; Jacob, M. Circular Economy Contributions to the Tourism Sector: A Critical Literature Review. Sustainability 2020, 12, 4338. [CrossRef]

23. Elkington, J. Cannibals with Forks: The Triple Bottom Line of 21st Century Business; New Society Publishers: Gabriola Island, BC, Canada, 1998. 
24. Cecchin, A.; Salomone, R.; Deutz, P.; Raggi, A.; Cutaia, L. Relating Industrial Symbiosis and Circular Economy to the Sustainable Development Debate. In Industrial Symbiosis for the Circular Economy: Operational Experiences, Best Practices and Obstacles to a Collaborative Business Approach; Salomone, R., Cecchin, A., Deutz, P., Raggi, A., Cutaia, L., Eds.; Strategies for Sustainability; Springer International Publishing: Cham, Switzerland, 2020; pp. 1-25.

25. Millar, N.; McLaughlin, E.; Börger, T. The Circular Economy: Swings and Roundabouts? Ecol. Econ. 2019, 158, 11-19. [CrossRef]

26. Falcone, P.M. Tourism-based circular economy in Salento (South Italy): A SWOT-ANP analysis. Soc. Sci. 2019, 8, 216. [CrossRef]

27. Girard, L.F.; Nocca, F. From Linear to Circular Tourism. Aestimum 2017, 70, 51-74. [CrossRef]

28. Jones, P.; Wynn, M.G. The circular economy, natural capital and resilience in tourism and hospitality. Int. J. Contemp. Hosp. Manag. 2019, 31, 2544-2563. [CrossRef]

29. Patti, S. Circular economy and sharing consumption: Attitudes towards low-carbon tourism. Econ. Policy Energy Environ. 2017, 1-2, 219-234. [CrossRef]

30. Immacolata, V. Agriculture, rural tourism and circular paradigm. Qual. Acc. Succ. 2018, 19, 556-562.

31. Naydenov, K. Circular tourism as a key for eco-innovations in circular economy based on sustainable development. In Proceedings of the 18th International Multidisciplinary Scientific GeoConference SGEM, Albena, Bulgaria, 30 June-9 July 2018; SGEM Scientific Papers DataBase: Sofia, Bulgaria, 2018; pp. 135-142.

32. Rezaee, Z;; Choi, E.K. The relevance of business sustainability in the hotel industry. In Sustainability in Hospitality: How Innovative Hotels are Transforming the Industry, 1st ed.; Gardetti, M.A., Torres, A.L., Eds.; Greenleaf Publishing Limited: Sheffield, UK, 2016; pp. $25-40$.

33. Gardetti, M.A.; Torres, A.L. Introduction. In Sustainability in Hospitality: How Innovative Hotels Are Transforming the Industry, 1st ed.; Gardetti, M.A., Torres, A.L., Eds.; Greenleaf Publishing Limited: Sheffield, UK, 2016; pp. 1-6.

34. Chaw, L.Y.; Tang, C.M. Online accommodation booking: What information matters the most to users? Inform. Technol. Tour. 2019, 21, 369-390. [CrossRef]

35. Koroleva, I.S.; Vishnevskaya, E.V. Dynamics of tourist services in the context of digital technology development. Serv. Plus 2020, $14,12-21$.

36. Arzoumanidis, I.; Petti, L.; Raggi, A. Life Cycle Thinking in online accommodation booking platforms: Making a more sustainable choice. In Life Cycle Thinking in Decision-Making for Sustainability: From Public Policies to Private Businesses, Proceedings of the 12th Italian LCA Network Conference, Messina, Italy, 11-12 June 2018; Mondello, G., Mistretta, M., Salomone, R., Dominici Loprieno, A., Cortesi, S., Mancuso, E., Eds.; ENEA: Frascati, Italy, 2018; pp. 129-137.

37. Raggi, A.; Arzoumanidis, I.; Petti, L. Life Cycle Thinking for sustainable tourism in online booking platforms. In Smart Tourism; Cantino, V., Culasso, F., Racca, G., Eds.; McGraw-Hill Education: Milan, Italy, 2018; pp. 111-121.

38. Arzoumanidis, I.; Walker, A.M.; Petti, L.; Raggi, A. Measuring circularity in the tourism sector: A step forward. In La Sostenibilità della LCA Tra Sfide Globali e Competitività delle Organizzazioni, Proceedings of the 14th Italian LCA Network Conference, Cortina D'Ampezzo, Italy, 9-11 December 2020; in press.

39. EBSCO Discovery Service. Discovery@Ud'A. Available online: https://polouda.sebina.it/SebinaOpacChieti/.do (accessed on 20 August 2021).

40. Schianetz, K.; Kavanagh, L.; Lockington, D. Concepts and Tools for Comprehensive Sustainability Assessments for Tourism Destinations: A Comparative Review. J. Sustain. Tour. 2007, 15, 369-389. [CrossRef]

41. Kristjánsdóttir, K.R.; Ólafsdóttir, R.; Ragnarsdóttir, K.V. Reviewing integrated sustainability indicators for tourism. J. Sustain. Tour. 2017, 26, 583-599. [CrossRef]

42. Caldeira Sanches, A.; Sauer, L.; Binotto, E. Analysis of studies on sustainability indicators in tourism an integrative review. Tur. Anál. 2018, 29, 292-311.

43. Manrai, L.A.; Manrai, A.K.; Friedeborn, S. Environmental determinants of destination competitiveness and its Tourism AttractionsBasics-Context, A-B-C, indicators: A review, conceptual model and propositions. J. Econ. Finance Adm. Sci. 2020, 25, 425-449. [CrossRef]

44. Rasoolimanesh, S.M.; Ramakrishna, S.; Hall, C.M.; Esfandiar, K.; Seyfi, S. A systematic scoping review of sustainable tourism indicators in relation to the sustainable development goals. J. Sustain. Tour. 2020, 1-21. [CrossRef]

45. Filimonau, V. Reviewing the Carbon Footprint Assessment of Tourism: Developing and Evaluating Life Cycle Assessment (LCA) to Introduce a More Holistic Approach to Existing Methodologies. Ph.D. Thesis, Bournemouth University, Bornemouth, UK, 2011.

46. Cavalcanti Falcão, M.; Pasa Gómez, C. Analysis of the Sustainability of Tourism Destinations: A theoretical proposal for adapting the Tourism Areas Life Cycle Model to the Dimensions of Sustainability. Tur. Visão e Ação 2012, 14, 304-321. (In Portuguese)

47. Soares, J.C.; Gandara, J.M.; Baidal, J.I. Indicators to analyze the life cycle of coastal tourist destination. Investig. Tur. 2012, 3, 19-38. (In Spanish)

48. Arcese, G.; Lucchetti, M.C.; Merli, R. Social Life Cycle Assessment as a Management Tool: Methodology for Application in Tourism. Sustainability 2013, 5, 3275-3287. [CrossRef]

49. Filimonau, V. Tourism, Environmental Impacts and Their Assessment: An Introduction. In Life Cycle Assessment (LCA) and Life Cycle Analysis in Tourism: A Critical Review of Applications and Implications; Springer: Cham, Switzerland, 2016.

50. Kulkajonplun, K.; Angkasith, H.V.; Rithmanee, D. The development of a sustainable resort and indicators. Procedia CIRP 2016, 40, 191-196. [CrossRef] 
51. Michailidou, A.V.; Vlachokostas, C.; Moussiopoulos, N.; Maleka, D. Life Cycle Thinking used for assessing the environmental impacts of tourism activity for a Greek tourism destination. J. Clean. Prod. 2016, 111, 499-510. [CrossRef]

52. Steinmann, Z.J.N.; Schipper, A.M.; Hauck, M.; Huijbregts, M.A.J. How many environmental impact indicators are needed in the evaluation of product life cycles? Environ. Sci. Technol. 2016, 50, 3913-3919. [CrossRef]

53. Kalbar, P.P.; Birkved, M.; Karmakar, S.; Nygaard, S.E.; Hauschild, D.M. Can carbon footprint serve as proxy of the environmental burden from urban consumption patterns? Ecol. Indic. 2017, 74, 109-118. [CrossRef]

54. Puig, R.; Kiliç, E.; Navarro, X.; Albertí, J.; Chacón, L.; Fullana-i-Palmer, P. Inventory analysis and carbon footprint of coastlandhotel services: A Spanish case study. Sci. Total Environ. 2017, 595, 244-254. [CrossRef]

55. Todorovic, B. The importance of life cycle on the future development of tourist destination. Cent. Eur. Stud. (CES) Work. Pap. 2019, 11, 143-156.

56. Zagonari, F. Multi-Criteria, Cost-Benefit, and Life-Cycle Analyses for Decision-Making to Support Responsible, Sustainable, and Alternative Tourism. Sustainability 2019, 11, 1038. [CrossRef]

57. Cavallin Toscani, A.; Macchion, L.; Stoppato, A.; Vinelli, A. How to assess events' environmental impacts: A uniform life cycle approach. J. Sustain. Tour. 2021, 1-20. [CrossRef]

58. Soratana, K.; Landis, A.E.; Jing, F.; Suto, H. The role of Life Cycle Approaches in Sustainable Development of Tourism. In Supply Chain Management of Tourism towards Sustainability; Springer: Cham, Switzerland, 2021; pp. 13-29.

59. Zhao, D.P.; Tao, H. Indicator System Construction for Circular Economy Assessment of Tourism Spots: A case study of Sand Lake and Shapotou Tourism Spots in Ningxia, China. J. Desert Res. 2011, 6, 1521-1526. (In Chinese)

60. Scheepens, A.E.; Vogtländer, J.G.; Brezet, J.C. Two Life Cycle Assessment (LCA) Based Methods to Analyse and Design Complex (Regional) Circular Economy Systems. Case: Making Water Tourism More Sustainable. J. Clean. Prod. 2016, 114, 257-268. [CrossRef]

61. Maugeri, E.; Gullo, E.; Romano, P.; Spedalieri, F.; Licciardello, A. The Bioeconomy in Sicily: New Green Marketing Strategies Applied to the Sustainable Tourism Sector. Procedia Environ. Sci. Eng. Manag. 2017, 4, 135-142.

62. Nocca, F. The Role of Cultural Heritage in Sustainable Development: Multidimensional Indicators as Decision-Making Tool. Sustainability 2017, 9, 1882. [CrossRef]

63. Pan, S.-Y.; Gao, M.; Kim, H.; Shah, K.J.; Pei, S.-L.; Chiang, P.-C. Advances and Challenges in Sustainable Tourism toward a Green Economy. Sci. Total Environ. 2018, 635, 452-469. [CrossRef]

64. Randazzo, M.; Gulisano, E.; Puleo, R.; Parisi, A.; Gatta, C.D. Territorial and Ambiental Retraining of Pantelleria's Island in a Circular Economy View: Implementation of Renewable Energy Sources as a Lever of Economic Improvement. Procedia Environ. Sci. Eng. Manag. 2019, 6, 237-244.

65. Son, L.H.; Matsui, Y.; Trang, D.T.T.; Thanh, N.P. Estimation of the Solid Waste Generation and Recycling Potential of the Hotel Sector: A Case Study in Hue City, Vietnam. J. Environ. Prot. 2018, 9, 751-769. [CrossRef]

66. Hartley-Ballestero, M.; Suárez-Espinoza, K. Exportación de Servicios Turísticos: ¿un Sector Estratégico Para Enfrentar El Cambio Climático En Costa Rica? Revista EAN 2020, 1-26. (In Spanish) [CrossRef]

67. Voukkali, I.; Loizia, P.; Navarro Pedreño, J.; Zorpas, A.A. Urban Strategies Evaluation for Waste Management in Coastal Areas in the Framework of Area Metabolism. Waste Manage. Res. 2021, 39, 448-465. [CrossRef]

68. Krippendorff, K. Content Analysis-Introduction to Its Methodology, 4th ed.; Sage Publications: Thousand Oaks, CA, USA, 2018.

69. United Nations Environment Programme (UNEP). Guidelines for Social Life Cycle Assessment of Products and Organisations 2020; UNEP: Geneva, Switzerland, 2020.

70. Chris, H.; Sirakaya, E. Sustainability indicators for managing community tourism. Tour. Manag. 2006, 27, 1274-1289.

71. Castellani, V.; Sala, S. Sustainable performance index for tourism policy development. Tour. Manag. 2010, 31, 871-880. [CrossRef]

72. Blancas, F.J.; González, M.; Lozano-Oyola, M.; Pérez, F. The assessment of sustainable tourism: Application to Spanish coastal destinations. Ecol. Indic. 2010, 10, 484-492. [CrossRef]

73. Butler, R. The Concept of Tourist Area Cycle of Evolution: Implications for Management of Resources. Can. Geogr. 1980, 24, 5-12. [CrossRef]

74. Vargas-Sánchez, A. The unavoidable disruption of the circular economy in tourism. Worldw. Hosp. Tour. Themes 2018, $10,652-661$. [CrossRef]

75. Khodaiji, J.D.; Christopoulou, D. Sustainable development and the circular economy in Greece: Case examples from Costa Navarino and Grecotel. Worldw. Hosp. Tour. Themes 2020, 12, 609-621. [CrossRef]

76. Manniche, J.; Larsen, K.T.; Broengaard, R.B.; Holland, E. Destination: A Circular Tourism Economy A Handbook for Transitioning Toward a Circular Economy within the Tourism and Hospitality Sectors in the South Baltic Region; Centre for Regional \& Tourism Research: Nexoe, Denmark, 2020.

77. Rodríguez-Antón, J.M.; del Alonso-Almeida, M.M. The Circular Economy Strategy in Hospitality: A Multicase Approach. Sustainability 2019, 11, 5665. [CrossRef]

78. Salehi, M.; Filimonau, V.; Asadzadeh, M.; Ghaderi, E. Strategies to improve energy and carbon efficiency of luxury hotels in Iran. Sustain. Prod. Consum. 2021, 26, 1-15. [CrossRef]

79. Organisation for Economic Co-operation and Development (OECD). OECD Environmental Indicators: Development, Measurement and Use; OECD: Paris, France, 2003.

80. United Nations (UN). Indicators of Sustainable Development: Guidelines and Methodologies; United Nations: New York, NY, USA, 2007.

81. European Environment Agency (EEA). Environmental Indicators: Typology and Overview; EEA: Copenhagen, Denmark, 1999. 